\title{
ISLAMIC MODELS OF SAVING AND INVESTMENT SEBAGAI SUATU TAWARAN ATAS PERILAKU IMPULSE BUYING PADA PRODUK DAN JASA TAHSIINIIYĀT
}

\author{
Ika Yunia Fauzia \\ Sekolah Tinggi Ilmu Ekonomi Perbanas Surabaya, Indonesia \\ E-mail: ika.yunia@perbanas.ac.id
}

\begin{abstract}
The behavior of impulsive buying becomes common today, along with the rampant variety of marketing promotions carried out by business people. Many consumers make purchases impulsively after being attracted to several factors that drive this behavior. The purchases due to unplanned decisions often occur in products and services of tabsiniyat. Actually, there is nothing wrong with the behavior of impulsive buying, if the consumers who do it have fulfilled the darüryat needs and have prepared their future needs. However, it becomes a problem if impulsive buying for products and services of tahsiniy at precede the primary needs that have not been fulfilled properly. This research will try to provide a brief solution on how to limit the self from rughbah and shabwah of buying, by planning income for several financial posts. Here the author offers the concept of Islamic models of saving and investment which can also be interpreted as Islamic family wealth management. It is hoped that this research can provide a meaningful contribution to human development which results in the development of families, society and country.
\end{abstract}

Keywords: Impulsive buying; products and services of tahsiniyät, islamic models of saving and investment.

\section{Pendahuluan}

Berbagai macam kajian dan penelitian yang membahas tentang perilaku pembelian selalu marak, dikarenakan penelitian di bidang ini memberikan sumbangsih yang besar pada dunia bisnis dan industri. ${ }^{1}$

\footnotetext{
1 Tidak ada yang salah dengan berbagai macam riset tentang perilaku pembelian, yang termasuk di dalamnya adalah riset tentang impulse buying yang dilakukan oleh banyak kalangan, karena hal ini menguntungkan para pelaku bisnis. Hal ini dikarenakan tujuan dari bisnis adalah untuk mendapatkan keuntungan (profit),
} 
Perkembangan pemikiran tentang bagaimana cara-cara untuk mengenali konsumen dalam mengambil sebuah keputusan dalam pembelian merupakan sesuatu yang selalu berkembang dengan pesat. Salah satu riset yang banyak dilakukan oleh banyak peneliti adalah bagaimana memahami seorang konsumen melakukan suatu pembelian yang tidak terencana, ketika para penjual dan produsen menawarkan produk/jasa mereka. Pembelian yang tidak terencana dikenali dengan sebutan impulse buying, yang digerakkan oleh pemikiran jangka pendek seseorang untuk membeli karena disebabkan oleh beberapa faktor. Faktor-faktor yang menyebabkan seorang konsumen melakukan impulse buying kemudian berkembang dalam riset di area manajemen, bisnis, kewirausahaan dan psikologi ekonomi, sehingga hasil dari riset tersebut bisa dimanfaatkan oleh para produsen dan penjual.

Beberapa faktor yang mempengaruhi impulse buying di antaranya adalah merk, kinerja, dan teknologi. ${ }^{2}$ Keterlibatan konsumen dalam fashion, karakteristik kepribadian, lingkungan toko, ${ }^{3}$ kenaikan pendapatan disposable konsumen dan ketersediaan layanan kartu kredit ${ }^{4}$ juga menjadi faktor yang mempengaruhi impulse buying. Menurut Han, Morgan, Kotsiopulos dan Kang-Park, ada empat tipe perilaku impulse buying: pertama, pure impulse buying (pembelian yang dilakukan karena adanya keinginan tiba-tiba dari konsumen, hal ini di luar kebiasaan konsumen tersebut); kedua, reminded impulse buying (ingatan konsumen terhadap suatu keadaan-bisa jadi karena pengaruh iklan-yang menjadikannya merasa membutuhkan produk tersebut); ketiga, planned

mempertahankan kelangsungan hidup perusahaan, pertumbuhan sosial dan tanggung jawab sosial. Pelaku bisnis ketika memasuki suatu pasar harus siap menghadapi persaingan dengan pelaku bisnis lainnya, maka dari itu diperlukan strategi pemasaran untuk bisa menggerakkan konsumen untuk melakukan pembelian. Lihat Ika Yunia Fauzia, Etika Bisnis dalam Islam (Jakarta: Prenada Media Kencana, Cet. Ke-3, 2017), 3-4.

2 J. Krishnan dan M.V. Bhuvaneswari, "A Review of Literature on Impulse Buying Behaviour of Consumers in Brick dan Mortar and Click Only Stores", International Journal of Management Research and Social Science (IJMRSS), Vol. 2, No. 3 (2015), 84-90.

${ }^{3}$ Vazifehdoost, H., A. Rahnama, S. J. Mousavian, "Evaluation of The Influence of Fashion Involvement, Personality Characteristics, Tendency to Hedonic Consumption and Store Environtment on Fashion-Oriented Impulse Buying", Mediterranean Journal of Social Sciences (MCSER Publishing Rome-Italy), Vol. 5, No. 16 (2014), 223-231.

${ }^{4}$ H. Dittmar dan J. Drury, "Self Image-Is It the Bag? A Qualitative Comparison Between Ordinary and Excessive Consumers", Journal of Economic Psychology, Vol. 21, No. 2 (2000). 
impulse buying (konsumen terbiasa menunggu adanya penawaran menarik seperti diskon dan promo untuk melakukan pembelian); keempat, fashion-oriented impulse buying (pembelian fashion yang tidak terencana, terjadi karena konsumen terpengaruh oleh gaya atau style baru yang terus berkembang). ${ }^{5}$

Perilaku impulse buying selama ini banyak terkonsentrasi pada produk dan jasa tersier (tabsiniy $\bar{a}$ ), menjadi sebuah antitesis dalam pembangunan ekonomi keluarga. Keputusan pembelian suatu produk/jasa sangat dipengaruhi oleh kepuasan seseorang, walaupun hal tersebut belum tentu sesuai dengan kemaslahatan. Seseorang bisa merasakan kepuasan ketika melakukan pembelian yang tidak terencana, akan tetapi bisa jadi keputusan tersebut akan merugikan keuangan keluarga. Bentuk kerugian bisa dirasakan secara langsung, apabila seseorang lebih mengedepankan impulse buying pada produk dan jasa tahsiniyät (tersier) padahal kebutuhan darürȳät (primer)nya belum terpenuhi. Bentuk kerugian bisa juga dirasakan tidak secara langsung, jikalau seseorang lebih mengedepankan impulse buying pada produk dan jasa tahsiniyat, akan tetapi ia belum mengalokasikan dana untuk saving dan investasi. Artikel ini memberikan satu tawaran yang menarik, tentang Islamic models of saving and investment dan Islamic family wealth management, dalam rangka untuk membangun perekonomian keluarga.

\section{Perilaku Impulse Buying Konsumen Muslim}

Perilaku impulse buying bisa digerakkan oleh life style dan fashion involvement, seiring dengan bertambahnya pendapatan masyarakat. Dinamika perkembangan bisnis retail di Indonesia merupakan salah satu hal yang memicu perkembangan gaya hidup dan pola belanja masyarakat. Masyarakat dengan bigh income, menunjukkan pola pengeluaran belanja yang fluktuatif dan seringkali melesat dari perencanaan keuangan yang mereka buat. ${ }^{6}$ Perilaku konsumtif banyak digerakkan oleh pembelian yang tidak terencana yang dilakukan oleh konsumen. Di era digital seperti saat ini banyak perilaku impulsif yang dilakukan oleh konsumen karena dampak respons emosi yang

\footnotetext{
${ }^{5}$ Han Y.K., Morgan, Kotsiopulos dan Kang-Park, "Impulse Buying Behavior of Apparel Purchasers", Clothing and Textiles Research Journal, Vol. 9, No. 3 (1991), 1521.

${ }^{6}$ Edwin Japarianto dan Sugiono Sugiharto, "Pengaruh Shopping Life Style dan Fashion Involvement terhadap Impulse Buying Behavior Masyarakat High Income Surabaya", Jurnal Manajemen Pemasaran, Vol. 6, No. 1 (2011), 32-41.
} 
diperoleh dari stimulus media iklan yang diformat dalam bentuk audio-visual, animasi gambar dan teks gambar. ${ }^{7}$ Pemasaran secara offline dan online $e^{8}$ juga mampu menggerakkan konsumen sehingga terjadi perilaku pembelian yang tidak terencana untuk produk ataupun jasa.

Impulse buying adalah pembelian yang tidak terencana pada suatu produk, yang dipengaruhi secara signifikan oleh keterlibatan konsumen pada produk tersebut. ${ }^{9}$ Pembelian tanpa rencana ini dilakukan oleh konsumen, yang sebelumnya tidak mempunyai keinginan dalam menentukan merk dan mempunyai niat untuk membeli. Hal ini karena adanya tawaran hot promo, diskon, iklan, pengaruh salesperson, suasana outlet dan lain sebagainya, yang pada akhirnya banyak konsumen yang kemudian melakukan pembelian tanpa adanya rencana sebelumnya. ${ }^{10}$ Perilaku impulsif yang dilakukan oleh konsumen juga mengintegrasikan konsep situasional, reaksi impulsif, nilai hedonis, nilai utilitarian, nilai pelanggan, kepuasan dan loyalitas pelanggan. Konsep situasional terkait dengan situasi di mana

7 Hatane Semuel, "Dampak Respon Emosi terhadap Kecenderungan Perilaku Pembelian Impulsif Konsumen Online dengan Sumberdaya yang Dikeluarkan dan Orientasi Belanja Sebagai Variabel Mediasi”, Jurnal Manajemen dan Kewirausahaan, Vol 2, No. 2 (2006), 101-116.

8 Perkembangan bisnis online sangatlah cepat sekali seperti tumbuhnya jamur di musim hujan, seiring dengan berkembangnya berbagai macam teknologi berupa gadget, ipad, android, dan teknologi lainnya, dengan didukung mudahnya akses penggunaan internet di manapun konsumen berada. Konsumen bisa berbelanja hanya dengan menekan satu tombol pembelian saja dan mentransfer uang dengan menggunakan layanan internet banking dan mobile banking. Berbagai kemudahan kemudahan inilah yang juga turut menyuburkan perilaku impulse buying pada produk dan jasa tahsiniya àt, khususnya untuk produk dan jasa online. Lihat Ika Yunia Fauzia, "Transcendental Trust dalam Bisnis Online di Kalangan Pengusaha Garment di Indoensia" (Surabaya: Penelitian Internal PPPM STIE Perbanas Surabaya, 2016); Ika Yunia Fauzia, "Hambatan dalam Pemanfaatan Layanan Internet Banking dan Mobile Banking di Perbankan Syariah Bagi Pelaku Bisnis Online" (Surabaya: Penelitian Internal PPPM STIE Perbanas Surabaya, 2017); Ika Yunia Fauzia, "Pemanfaatan E-Commerce dan M-Commerce dalam Bisnis di Kalangan Wirausahawan Perempuan di Indonesia", Journal of Business and Banking, Vol. 5, No. 2 (2015), 237 256; Ika Yunia Fauzia, "Akad Wakalah dan Samsarah sebagai Solusi atas Klaim Keharaman Dropship dalam Jual Beli Online”, Islamica: Jurnal Studi Keislaman, Vol. 9, No. 2 (2015), 323-343.

9 Han Y.K., et.al. "Impulse Buying”, 15-21.

${ }^{10}$ E.J. Park, Kim dan Fourney, "A Structural Model of Fashion-Oriented Impulse Impulse Buying Behaviour", Journal of Fashion Marketing and Management, Vol. 10, No. 4 (2006), 433-446. 
konsumen melakukan keputusan untuk melakukan pembelian secara impulsif. Faktor situasional merupakan lingkungan sementara yang membentuk konteks dalam suatu kegiatan konsumen, yang terjadi pada waktu dan tempat tertentu. Konsep situasional mencakup lingkungan fisik, lingkungan sosial, waktu, tujuan berbelanja dan suasana hati ketika berbelanja. Beberapa hasil studi menyatakan bahwa faktor situasional yang termasuk di dalamnya adalah design product, music, layout, decoration, karyawan, ketersediaan produk, kondisi toko berdesakan dan ketersediaan tempat parkir secara positif berhubungan dengan nilai yang dirasakan oleh konsumen. Situasi ini dapat menimbulkan reaksi yang impulsif dan mendorong terjadinya keputusan dalam pembelian. Adapun nilai hedonis berupa pengalaman yang berhubungan dengan perasaan, fantasi, kesenangan, dan panca indera. Nilai hedonis yang tinggi mempengaruhi kepuasan konsumen. Adapun nilai konsumsi utilitarian menggambarkan berbelanja dengan mentalitas kerja, karena pelanggan menganggap bahwa berbelanja merupakan aktivitas yang harus dilakukan untuk mendapatkan barang yang dibutuhkan. Nilai ulitarian biasanya didasarkan pada pertimbangan rasional untuk memaksimalisir nilai penggunaan. Nilai pelanggan, kepuasan, dan loyalitas pelanggan juga merupakan salah satu penggerak perilaku pembelian yang tidak terencana, selain beberapa bahasan di atas. ${ }^{11}$

Pemasaran yang dilakukan dengan cara agresif dan persuasif dewasa ini juga memunculkan berbagai macam perilaku pembelian dari berbagai macam konsumen. Tidak terkecuali di dalamnya adalah para konsumen Muslim. Banyak di antara konsumen yang kemudian masuk ke dalam area impulse buying, yaitu suatu kondisi pembelian yang tidak direncanakan sejak awal. Dari beberapa wawancara yang dilakukan oleh penulis, konsumen perempuan lebih banyak melakukan impulse buying, terutama ketika berkaitan dengan pembelian secara online untuk produk-produk garmen dan fashion. ${ }^{12}$ Faktor keterlibatan konsumen pada produk fashion merupakan salah satu penyebab adanya pembelian yang tidak terencana. Pakaian merupakan produk yang paling memungkinkan untuk dibeli secara impulsif

\footnotetext{
11 Fatchur Rohman, "Peran Nilai Hedonik Konsumsi dan Reaksi Impulsif sebagai mediasi Pengaruh Faktor Situasional terhadap Keputusan Pembelian Impulsif di Butik Kota Malang”, Jurnal Aplikasi Manajemen, Vol 7, No. 2 (2009), 251-261.

12 Ika Yunia Fauzia dan Aniek Masudah Ilfitriah, "Perilaku Impulse Buying pada Produk Woman Fashion di Kalangan Konsumen Bisnis Online" (Surabaya: Penelitian Internal PPPM STIE Perbanas Surabaya, 2017), 15.
} 
dikarenakan produk fashion memberikan nilai guna dan menawarkan nilai hedonis pada konsumen. Bisa jadi sebagai indentitas diri bagi pria maupun wanita yang menyukai fashion. Banyak di antara konsumen yang berusaha untuk tampil secara maksimal dan berusaha menjadi fashionable dengan selalu mengikuti trend yang selalu berkembang. Perkembangan fashion juga mendorong konsumen untuk melakukan pembelian yang tidak terencana sehingga memunculkan fashion-orientedimpulse buying. Pembelian yang tidak terencana pada produk-produk fashion juga dipengaruhi oleh beberapa hal, di antaranya adalah pesan iklan yang ada, kaitan emosional dan fashion-oriented impulse buying. ${ }^{13}$ Konsumen yang melakukan pembelian secara impulsif merasakan sebuah keinginan yang mendadak, ketika ingin membeli suatu produk/jasa. Terkadang dikarenakan beberapa faktor saja, cukup dengan bilangan detik seorang konsumen akan tergerak untuk membeli suatu produk/jasa tertentu.

Maraknya pembelian impulse buying tidak bisa dilepaskan dari pola konsumsi masyarakat Indonesia yang sangat tinggi. Indonesia dengan penduduk Muslim yang terbesar di dunia, mempunyai pola konsumsi yang tinggi sehingga mengalahkan beberapa negara lainnya. Otoritas Jasa Keuangan (OJK) menyatakan bahwa masyarakat Indonesia semakin konsumtif dan mulai meninggalkan kebiasaan menabung, karena masyarakat lebih banyak mengeluarkan uang mereka untuk konsumsi daripada untuk menabung. Tren penurunan marginal propensity to save (MPS) terjadi sejak 2011 dan pada akhir 2013 akhir, rasio tersebut berada di bawah marginal propensity to consume (MPC). ${ }^{14}$ Meningkatnya tingkat konsumsi masyarakat dikarenakan meningkatnya pendapatan mereka, yang kemudian menciptakan kelas baru dalam masyarakat. Kelas baru dalam masyarakat karena meningkatnya pendapatan mereka, tanpa diimbangi dengan pengetahuan literasi keuangan yang memadai sehingga menghasilkan masyarakat yang konsumtif. Adanya iklan, promo, dan gaya hidup yang tinggi, menjadikan keputusan dalam konsumsi masyarakat tidak dilandasi oleh kebutuhan dan juga pembelian yang terencana. Pembelian yang tidak terencana (impulse buying) seringkali banyak

13 A. O'Cass, "Fashion Clothing Consumption: Antencedents and Consequences of Fashion Clothing Involvement”, European Journal of Marketing, Vol. 38, No. 7 (2004), 869-882.

14 “OJK: Orang Indonesia Makin Konsumtif”, dalamhttps://ekonomi.kompas.com / read/2015/08/08/110746226/Diunduh 14 Maret 2018, pukul 19.00. 
dijumpai untuk kasus pembelian produk dan jasa taḩsinȳyat, sehingga terkadang dijumpai kalangan keluarga yang miskin, kerapkali bisa membeli produk dan jasa tab̧sinìyät, sekalipun mereka belum bisa memenuhi kebutuhan darürȳyat-nya.

Berdasarkan data BPS, Produk Domestik Bruto (PDB) per-kapita, selama beberapa tahun terakhir terus mengalami peningkatan. Kondisi ini menunjukan bahwa tingkat pendapatan masyarakat Indonesia semakin meningkat. Namun survei Nasional Literasi Keuangan OJK 2013 menunjukkan tingkat pengetahuan keuangan masyarakat sebesar $21,84 \%$ atau hanya sekira seperlima penduduk Indonesia yang teredukasi dengan baik (well literate) soal keuangan. ${ }^{15}$ Lebih jauh lagi, menurut data dari The Nielsen Global Consumer Index yang dikutip oleh Reuters, menyebutkan bahwa penduduk Indonesia mempunyai tingkat konsumsi yang tinggi, tercatat pada kuartal terakhir 2013. Indonesia tercatat masih menjadi negara dengan tingkat konsumsi tertinggi pada kuartal IV-2013. Padahal penduduk Amerika Serikat (AS) pelan-pelan mulai mengurangi kebiasaan belanjanya. Dari data yang ada, Indonesia masih menjadi daftar negara yang teratas dengan tingkat konsumsi yang tertinggi untuk skala masyarakat di dunia. ${ }^{16}$ Sisi positif dari tingginya konsumsi masyarakat di Indonesia adalah ketika banyak permintaan maka berefek banyaknya suplai barang atau jasa yang diminta. Misalnya, ketika banyak permintaan di satu produk tertentu, maka akan membuka kran-kran produksi untuk barang yang sedang banyak diminati oleh masyarakat. Hal ini menjadi positif jika perilaku impulse buying terjadi pada produk dan jasa yang dihasilkan dari tangantangan penduduk Indonesia, para pelaku UMKM. Akan tetapi apabila barang yang banyak diminati oleh konsumen dengan cara pembelian yang tidak terencana adalah barang-barang impor, maka bisa diasumsikan bahwa banyak sekali uang penduduk Indonesia yang keluar karena dinikmati oleh para produsen asing.

Hal ini sejalan dengan kenyataan, bahwa banyak pengusaha asing tertarik dengan pasar Indonesia yang rata-rata masyarakatnya konsumtif. Indonesia sebagai negara yang besar baik dari segi jumlah penduduk maupun wilayah, menjadi daya tarik tersendiri bagi

15 Elisa Valenta Sari, "Pengelolaan Keuangan: OJK Pendapatan Meningkat, Masyarakat Cenderung Konsumtif', dalam https://www.cnnindonesia.com /ekonomi/20141220 232435-78-19533/ (Diunduh 14 Maret 2018, pukul 19.30)

16 "Penduduk Indonesia Paling Doyan Belanja di Dunia", dalam http://bisnis.liputan6.com/read/813277/ (diunduh 14 Maret 2018, pukul 19.15) 
pengusaha asing untuk berinvestasi. ${ }^{17}$ Maka, tidak mengherankan pada akhirnya jika konsumsi masyarakat Indonesia yang mayoritas Muslim, banyak terkonsentrasi pada produk dan jasa taḅsiniyät. Sehingga dengan didukung oleh pemasaran barang dan jasa tahsinìyat yang sangat marak sekali, maka permintaan akan barang dan jasa tersebut melesat ke atas dengan pesat.

Perilaku impulse buying berhubungan dengan adanya berbagai upaya pemasaran yang dilakukan oleh penjual baik secara online maupun offline. Banyaknya penelitian yang mengkaji tentang perilaku pembelian yang tidak terencana berbanding lurus dengan data-data yang ada, bahwa penduduk Indonesia merupakan objek yang sangat menarik untuk dijadikan konsumen, karena minat konsumsi yang tinggi, sehingga banyak sekali pengusaha asing yang tertarik untuk berinvestasi di Indonesia. Penduduk Indonesia juga merupakan salah satu penduduk yang paling suka berbelanja di bandingkan dengan penduduk dunia lainnya. Menjadi suatu keprihatinan adalah, belanja dan konsumsi yang tinggi dari penduduk Indonesia belum terkonsentrasi untuk kebutuhan primer (darürīyat), akan tetapi banyak tertuju pada belanja dan konsumsi untuk produk dan jasa tabsiniyàt. Selain itu penduduk Indonesia yang mayoritas Muslim juga masih tertinggal jauh dengan negara-negara lainnya untuk kategori saving dan investasi.

\section{Perilaku Impulse Buying pada Produk dan Jasa Tahssinñyāt}

Telah disebutkan di atas, bahwa seorang konsumen tergerak untuk melakukan impulse buying dikarenakan oleh beberapa hal, bisa jadi karena memang ada tawaran promosi, diskon dan iklan dari penjual, ataupun atmosfir dan layanan toko. Dari sisi konsumen, adanya pendapatan yang tinggi, pengaruh afektif dan kognitif, adanya shoping lifestyle dan kemudahan dalam transaksi online menjadi penggerak seseorang untuk cepat memutuskan untuk membeli suatu produk ataupun jasa.

Sebelum lebih jauh membahas tentang produk dan jasa tahsiniȳät, barang-barang ekonomi dikelompokkan menjadi beberapa macam, misalnya dari ketersediaan barang dapat dibedakan antara barang ekonomi dan barang non-ekonomi atau barang bebas; berdasarkan

17 Haryudi, "Masyarakat Indonesia Konsumtif, Daya Tarik Pengusaha Asing", dalam https://ekbis.sindonews.com/read/1061097/34/diunduh tanggal 18 Maret 2018, pukul 21.00. 
hubungannya dengan barang/jasa lainnya dikategorikan dengan barang substitusi dan komplementer; berdasarkan daya tahan ada barang tahan lama (durable goods) dan barang tidak tahan lama (nondurable goods); berdasarkan barang yang bisa dijadikan jaminan ada benda bergerak dan benda tidak bergerak, dan; berdasarkan prioritas pemanfaatannya ada barang primer, barang sekunder dan barang tersier. Barang primer setara dengan al-bäjìyàt al-darürȳyat yang mana ketika manusia tidak bisa mendapatkan produk/jasa tersebut, maka akan terganggu stabilitas hidupnya. Barang primer inilah yang biasa dipahami oleh banyak kalangan sebagai kebutuhan (needs), yang mampu menjaga kehidupan manusia dengan baik. Apabila manusia tidak bisa tercukupi kebutuhan-kebutuhannya, maka kehidupan akan menjadi sulit dan rusak. Kehidupan tidak bisa berjalan dengan baik, karena manusia tidak bisa hidup dengan cara yang baik. Contoh kebutuhan primer (darürìat) adalah sandang, pangan dan papan, sandang dalam artian baju sebagai pemenuhan kebutuhan dan bukan untuk motivasi hedonis, pangan dalam artian bahan makanan untuk menjaga kehidupan dan bukan penunjang lifestyle, dan papan dalam artian rumah untuk berteduh sebagai tempat tinggal.

Barang sekunder (bajiyyat) adalah kebutuhan yang apabila manusia tidak tercukupi maka tidak akan sampai pada derajat kerusakan dalam hidupnya. Misalnya ketika manusia sudah memiliki rumah, maka ia ingin membeli mesin cuci, kulkas, dan lain sebagainya. Misalnya ketika seseorang yang menginginkan makanan bergizi tersedia di rumahnya dan juga menginginkan pendidikan yang baik untuk anak-anaknya, ini adalah contoh dari kebutuhan sekunder. Berpakaian yang bagus, memiliki kendaraan yang bagus juga merupakan kebutuhan sekunder, agar bisa mempermudah aktivitas yang dilakukan oleh manusia.

Bahasan setelah kebutuhan sekunder adalah kebutuhan tersier atau dalam terminologi penulis dianggap sebagai suatu keinginan (wants). Kemauan manusia untuk mempertahankan eksistensinya dengan membeli apa yang menjadi keinginan-keinginannya masuk ke dalam bahasan tentang pemenuhan produk tahsiniya àt. Barang atau jasa tersier merupakan kebutuhan yang bersifat mewah, tidak sederhana dan berlebihan yang timbul setelah kebutuhan darürīyāt dan häjiȳät sudah terpenuhi. Terkadang pemenuhan seseorang akan produk dan jasa tahsiniyät hanya dikarenakan prestise semata, karena dapat meningkatkan status sosial seseorang dalam masyarakat. Menjadi suatu pertanyaan terbesar yang banyak terjadi dalam masyarakat 
adalah, apabila seseorang belum bisa memenuhi kebutuhan primer dan sekundernya, akan tetapi ia memaksakan diri memenuhi kebutuhan tersiernya. Misalnya seseorang lebih memilih untuk tidak menyekolahkan anaknya, agar uang yang dimilikinya bisa dibelikan gadget.

Ketiga kategori di atas mempunyai hubungan yang berjenjang, yaitu mulai dari kebutuhan yang terpenting (darüriyat), sampai dengan tahsiniyät (tersier). Kebutuhan darürìyät merupakan kebutuhan asas, dasar, basic, primer, elementer, fundamental dan pokok. Sementara häjiyaät adalah kebutuhan yang bersifat sekunder, suplementer dan untuk mempermudah manusia. Adapun keperluan yang bersifat tahsiniyàt bersifat tersier dan komplementer. Al-Shātibī menjelaskan beberapa hal yang terkait dengan ketiga hal di atas, yaitu: ${ }^{18}$

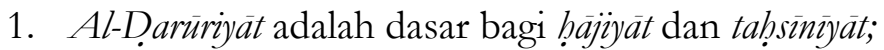

2. Kerusakan pada aspek-aspek darüriyät akan menyebabkan kerusakan pada seluruh aspek häjiỳät dan taḅsinìyāt;

3. Adapun jika terjadi kerusakan (kecil) pada aspek băjiȳät dan tabsiniyàt tidak akan menyebabkan kerusakan pada aspek darürīyät.

4. Jika misalnya terjadi kerusakan pada keseluruhan ḅäjȳät dan tahsiniyät, maka hal ini bisa menyebabkan kerusakan sebagaian dari darüriyāt ;

5. Perlindungan terhadap baj̄ìyàt dan taḥsinìyāt ada kalanya perlu untuk dipelihara terkait dengan perlindungan darürȳy $\bar{a} t$

Bisa dipahami bahwa kebutuhan manusia terdiri dari kebutuhan primer (darürìat) atau yang biasa dikenali dengan the basic needs (kebutuhan dasar), kemudian kebutuhan sekunder (häjiyatat) atau needs (kebutuhan) dan kebutuhan tersier (tahsinìyät) atau wants (keinginan). Menjadi penting untuk dibahas di sini adalah perilaku konsumen masyarakat yang banyak memenuhi kebutuhan taḥsinìät-nya melalui perilaku pembelian yang tidak terencana sebelum terpenuhi dua kebutuhan sebelumnya (darürìyat dan häjȳyat) yang berkaitan dengan keberlangsungan hidup mereka.

\section{Perilaku Impulse Buying Perspektif Maqāssid al-Sharī‘ah}

Tujuan sharī'ah adalah untuk merealisasikan kemaslahatan dan menghindari kerusakan (jalb al-masăliḥ wa dar' al-mafäsid). Tujuan

18 Al-Yasa Abu Bakar, Metode Istislahi Pemanfaatan Ilmu Pengetabuan dalam Ushul Fiqih (Banda Aceh: CV. Diandra Primamitra Media, 2012), 83-84. 
kemaslahatan ${ }^{19}$ berkaitan dengan bagaimana manusia bisa tercukupi berbagai macam kebutuhan darūrì ät-nya, dalam rangka untuk menjaga

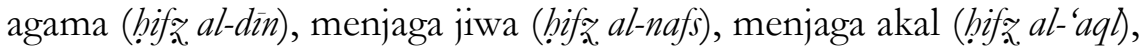

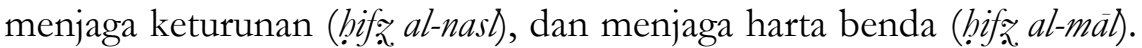
Apabila kebutuhan-kebutuhan darüriyät-nya tidak tercukupi, maka lima aspek di atas akan bisa rusak dan manusia tidak akan bisa hidup dengan baik.

Maqāsid al-sharíah secara etimologis terdiri dari dua kata, yaitu maqāsid dan sharīah. Maqāsid adalah bentuk plural dari maqșìd yang berarti kesengajaan ataupun tujuan. Sementara sharī'ah adalah jalan menuju air atau bisa diartikan jalan menuju ke arah sumber kehidupan. Arti dari maqāsid al-sharíab secara terminologi adalah penjagaan terhadap maksud dan tujuan sharī’ah, yaitu upaya mendasar untuk bertahan hidup, menahan faktor-faktor kerusakan dan mendorong terjadinya kesejahteraan. ${ }^{20}$ Maqāsid al-sharïab adalah tujuan-tujuan yang telah ditetapkan oleh shari'sah untuk dicapai demi kemaslahatan manusia. ${ }^{21}$ Maksud Allah selaku pembuat shari'‘ ah untuk memberikan kemaslahatan kepada manusia, yaitu dengan terpenuhinya ragam kebutuhan darürìah, häjiyah, dan tahsiniyah agar manusia bisa hidup dan dapat menjadi hamba Allah yang baik. ${ }^{22}$ Para ulama menyepakati bahwa sharīah diturunkan untuk membangun kemaslahatan manusia di dunia dan akhirat, sharī'ah diturunkan untuk dilaksanakan sesuai dengan maqāsid-nya agar kehidupan yang adil dapat ditegakkan dan kesejahteraan sosial dapat diwujudkan. ${ }^{23}$

\footnotetext{
${ }^{19}$ Kemaslahatan menurut Jalāl al-Dīn adalah segala sesuatu yang bermanfaat bagi manusia, yang dapat diraih oleh manusia dengan cara memperolehnya maupun menghindarinya. Lihat Jalāl al-Dīn 'Abd al-Raḥmān, al-Masālị̣ al-Mursalah (Mesir: Matba'at al-Sa'ādah, 1983), 12.

20 Abū Ḥāmid al-Ghazālī, Shifä’ al-Ghalìl, Hamdī Ubayd al-Kābish (ed.) (Baghdad: Maṭba'at al-Irshād, 1971), 159; Bin Zaghbah 'Izz al-Dīn, al-Maqāsid al-Ämmah li alSharīah al-Islämīyah (Kairo: Dār al-Ṣafwah li al-Ṭibā'ah wa al-Nashr wa al-Tawzī‘, 1996), 40.

21 Aḥmad al-Raysūnī, Nazarīyat al-Maqāsid 'ind al-Imām al-Shātibì (Beirut: al-Ma'had al-Ālì li al-Fikr al-Islām, al-Muassasah al-Jāmi iyah li al-Dirāsāt wa al-Nashr wa alTawzí' t.th), 45.

${ }^{22}$ Ika Yunia Fauzia dan Abdul Kadir Riyadi, Prinsip Dasar Ekonomi Islam Perspektif Maqashid al-Shariah (Jakarta: Prenada Media Kencana, Cet. Ke-3, 2017), 43.

${ }^{23}$ Ika Yunia Fauzia, "Urgensi Implementasi Green Economy Perspektif Pendekatan Dharuriyah dalam Maqashid al-Shariah", Jurnal Ekonomi dan Bisnis Islam, Vol. 2, No. 1 (2016), 87-104.
} 
Menurut Ibn Qayyim al-Jawzīyah dalam Jasser Auda menyebutkan bahwa shari'ah adalah suatu kebijaksanaan dan tercapainya perlindungan bagi setiap orang pada kehidupan dunia dan akhirat. Shari'ah merupakan keseluruhan dari keadilan, kedamaian, kebajikan dan kebaikan. Jadi, setiap aturan yang mengatasnamakan keadilan dengan ketidakadilan, kedamaian dengan pertengkaran, kebaikan dengan keburukan, kebijakan dengan kebohongan, adalah aturan yang tidak mengikuti shari'‘ah, walaupun hal tersebut diklaim sebagai interpretasi yang benar. ${ }^{24}$

Menurut Auda, maqāisid pertama adalah hikmah di balik suatu hukum $^{25}$; kedua, tujuan akhir yang baik yang hendak dicapai oleh suatu hukum; ketiga, kelompok tujuan ilahiah dan konsep moral yang menjadi basis dari hukum; keempat, kemaslahatan-kemaslahatan (masälib). Ketika seseorang mengkaji tentang maqāsid al-sharí'ah, maka nilai dan prinsip merupakan pokok yang paling utama. ${ }^{26}$ Penyataan Auda tentang keempat bahasan tentang maqāsid bisa ditelaah untuk menjadi alat analisis terkait dengan bagaimana tujuan-tujuan sharī'ah. Ketika berkaitan dengan adanya suatu hukum untuk pemenuhan kebutuhan yang primer (the basic needs), yang menjadi suatu pertanyaan adalah "apakah hikmah di balik penyediaan kebutuhan primer masyarakat bagi kehidupan?”, "apakah tujuan yang hendak dicapai ketika masyarakat diharuskan untuk mencukupi kebutuhan primer mereka?", "apakah tujuan ilahiah dan konsep moral yang menjadi suatu acuan ketika masyarakat bisa memenuhi kebutuhan primer mereka?" dan, "apakah ada kemaslahatan ketika masyarakat bisa memenuhi kebutuhan primer mereka?" Ketika disepakati bersama bahwa pemenuhan the basic needs masyarakat merupakan suatu hal yang harus diperhatikan dengan baik, maka harus dilakukan studi

\footnotetext{
${ }^{24}$ Jasser Auda, Maqasid al-Shari'ah as Philosophy of Islamic Law a System Approach (Herndon: The International Institut of Islamic Thought, 2008), xxii.

25 Al-Shātibī menyatakan bahwa yang dimaksud dengan illah adalah bikmah itu sendiri dalam bentuk maslahah dan mafsadab yang berkaitan dengan ditetapkannya perintah dan larangan. Baik keduanya bersifat zăhir atau tidak, mundabit atau tidak. Hikmah dan 'illah mempunyai hubungan yang sangat erat dalam rangka menetapkan suatu hukum. Hikmah merupakan sifat zähir tetapi tidak mundabit, dan hikmah baru menjadi 'illah setelah dinyatakan mundabit. Untuk itu maka perlu dicari mażinnät-nya, yaitu indikator yang menerangkan bahwa hikmah itu dapat dinyatakan sebagai mundabit. Lihat Abū Ishāa al-Shātịīi, al-Muwāfaqāt fì Usūul al-Aḥkām, Vol. 1 (t.t.: Dār al-Fikr, t.th.), 185.

${ }^{26}$ Auda, Maqāsid al-Shari'ah.
} 
mendalam tentang bagaimana mempermudah tujuan tersebut, termasuk juga meneliti tentang perilaku masyarakat yang bertentangan dengan hal di atas. Dari beberapa pertanyaan di atas, maka hal tersebut sesuai dengan apa yang ditulis oleh Fauzia bahwa sebuah aktivitas ekonomi seharusnya dibangun di bawah fondasi kemaslahatan, agar mempunyai efek yang mensejahterakan untuk menuju faläh. ${ }^{27}$

Menjadi sangat penting untuk mengakitkan perilaku impulse buying yang banyak berkembang di antara konsumen Muslim, dengan bahasan tentang bagaimana konsumsi perspektif maqāsid al-sharíah. Dalam maqāsid al-sharíah sudah dijelaskan dengan baik, bahwa konsumsi yang bertujuan untuk maslahah jauh bisa mensejahterakan daripada konsumsi yang hanya bertujuan pada kepuasan (utility) semata. Konsumsi yang digerakkan oleh perilaku pembelian yang tidak berencana memunculkan kepuasan pada diri konsumen, akan tetapi belum tentu mendatangkan kemaslahatan. Terlebih jika perilaku pembelian yang impulsif ini sangat berkaitan erat dengan pengadaan produk dan jasa tahsinìyät dan bukan mendukung terpenuhinya kebutuhan darürìyàt. Perilaku ini lebih banyak terkonsentrasikan pada produk dan jasa taḥsinìät, karena pemenuhan kebutuhan häjiyät dan darürȳyat lebih banyak digerakkan dengan motif pembelian yang terencana, yang tidak dilakukan secara impulsif.

Kebutuhan manusia dapat diukur dengan penjagaan lima hal yang merupakan inti dari kehidupan. Lima hal ini bisa disebut dengan alkullīyät al-khamsah atau al-darūrȳàt al-khamsah, yaitu penjagaan agama

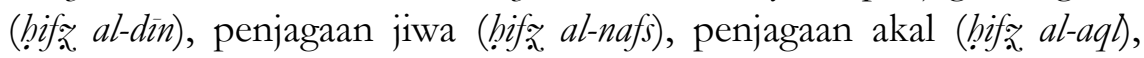
penjagaan keturunan (bifz al-nas) dan penjagaan harta benda (bif zal$m a \bar{t}$. Menjaga lima hal tersebut dilakukan dengan cara mendahulukan needs atau lebih tepatnya disebut dengan the basic needs, yaitu kebutuhan primer yang apabila manusia tidak bisa tercukupi maka kehidupannya akan menjadi rusak. Menjaga kelima hal di atas juga bisa dilakukan dengan membatasi wants, yaitu kebutuhan tersier. Keinginan manusia seringkali digerakkan oleh perilaku pembelian yang tidak terencana (impulse buying). Jika manusia bisa membatasi dirinya untuk masuk ke dalam perilaku pembelian yang tidak terencana, maka alokasi dana akan bisa terserap untuk mencukupi kebutuhan primer, saving,

${ }^{27}$ Ika Yunia Fauzia, "Studi Etnografi Makna Shariah Compliance bagi Pebisnis dan Wirausahawan Muslim di Indonesia" (Surabaya: Penelitian Internal PPPM STIE Perbanas Surabaya, 2018), 38. 
investasi dan memberdayakan masyarakat melalui amal saleh dengan mengeluarkan zakat, infak, sedekah dan wakaf.

\section{Islamic Models of Saving and Investment sebagai Antitesis Perilaku Impulse Buying}

Dari berbagai uraian di atas, ada sebuah tawaran yang ingin dipaparkan oleh penulis tentang Islamic models of saving and investment, sebagai antitesis perilaku impulse buying pada produk dan jasa tahsiniyāt. Spirit Islam mengajarkan bahwa esensi dalam mengatur keberlangsungan hidup, manusia haruslah pandai untuk mengatur keuangan pribadi dan keluarganya. Misalnya ada konsep nafaqah, yaitu sebuah proses pemberian nafkah dari kepala rumah tangga kepada bendahara rumah tangga (istri) adalah untuk dikelola dengan baik. Rumah tangga islami harus mempunyai Islamic family wealth management (manajemen kekayaan rumah tangga sesuai ajaran Islam), untuk menjaga keberlangsungan hidup dengan baik.

Islamic family wealth management berisi motivasi untuk mempersiapkan kehidupan di masa yang akan datang, dengan mengacu pada Islamic models of saving and investment. Penulis sengaja memberi label Islamic pada kalimat saving and investment, sebagai penegasan bahwa ada perintah dari Allah untuk mempersiapkan hari esok. Banyak sekali ajaran dalam al-Qur'ān dan Sunnah tentang bagaimana seharusnya mengelola keuangan rumah tangga, yaitu dengan menabung, berinvestasi, menghindari perilaku tabdhìr (mubazir) dan isräf (melewati batas), dan banyak sekali ajaran-ajaran lainnya.

Misalnya perintah untuk saving dan investasi dapat dipahami dari ajaran al-Qur'ān yang menceritakan kisah Nabi Yusuf pada masa panceklik, dan juga sebuah perintah untuk tidak meninggalkan keturunan dalam keadaan yang lemah. Islamic models of saving and investment bisa dimulai secara bersamaan ketika sebuah keluarga sudah merencanakan dengan baik kebutuhan darürìät mereka. Untuk memperjelas penjelasan di atas, berikut pemaparan tentang alokasi income untuk kebutuhan darürìyät dan kemudian dipaparkan islamic models of saving and investment:

Pertama, sebuah keluarga mempunyai seorang pemimpin, yaitu suami. Seorang suami berkewajiban untuk mengomunikasikan dengan sang istri sebagai bendahara keluarga untuk membuat perencanaan keuangan keluarga. Ketika ada pemasukan maka harus dialokasikan untuk: pertama, kebutuhan derürìyat dalam rangka menjaga agama, jiwa, 
akal, keturunan dan harta benda. Misalnya harus menjadi suatu pertimbangan di awal pernikahan, tentang suatu keputusan manakah yang harus dibeli terlebih dahulu, rumah atau mobil?

Kedua, bagian ini meniscayakan adanya upaya menyisihkan untuk saving, menabung dana yang ada untuk kebutuhan tidak terduga yang akan datang di hari esok. Motivasi dari aktivitas ini berdasarkan pada Q.S. Yūsuf [12]: 46-49, yaitu: Artinya, "Yusuf, wahai orang yang sangat dipercaya! Terangkanlah kepada kami (takwil mimpi) tentang tujuh ekor sapi betina yang gemuk yang dimakan oleh tujuh (ekor sapi betina) yang kurus, tujuh tangkai (gandum) yang hijau dan (tujuh tangkai) lainnya yang kering agar aku kembali kepada orang-orang itu, agar mereka mengetahui. (46) Dia (Yusuf) berkata, "Agar kamu bercocok tanam tujuh tahun (berturut-turut) sebagaimana biasa; kemudian apa yang kamu tuai hendaklah kamu biarkan di tangkainya kecuali sedikit untuk kamu makan. (47) Kemudian setelah itu akan datang tujuh (tahun) yang sangat sulit, yang menghabiskan apa yang kamu simpan untuk menghadapinya (tahun-tahun sulit), kecuali sedikit apa (bibit gandum) yang kamu simpan. (48) Setelah itu akan datang tahun, dimana manusia diberi hujan (dengan cukup) dan pada masa itu mereka memeras (anggur). (49)"

Dalam ayat di atas dijelaskan bahwa pada manusia tidak akan mengetahui masa depan yang akan dilaluinya, sehingga perlu mempersiapkan diri untuk menghadapi masa depan. Saving dengan tujuan untuk berjaga-jaga untuk kebutuhan darurat di masa depan merupakan suatu anjuran, seperti yang dijelaskan oleh Allah lewat cerita di atas. Ketika aktivitas saving diniatkan untuk menghindarkan perekonomian keluarga dari kerusakan, maka ini adalah bagian dari ibādah, yang mana aktivitas ini menuai pahala yang berlimpah. Aktivitas saving digunakan untuk kebutuhan yang tidak terduga, misalnya jika ada anggota keluarga yang masuk rumah sakit, untuk membayar kebutuhan darurat yang tidak terduga dan datang secara tiba-tiba, dan lain sebagainya;

Ketiga, bagian selanjutnya yang harus direncanakan melalui alokasi dana ketika seseorang mendapatkan penghasilan adalah investasi dengan motivasi ajaran dari surah al-Nisā' [4]: 9, yaitu: Artinya, "Dan hendaklah takut kepada Allah orang-orang yang seandainya meninggalkan dibelakang mereka anak-anak yang lemah, yang mereka khawatir terhadap (kesejahteraan) mereka. Oleh sebab itu hendaklah 
mereka bertakwa kepada Allah dan hendaklah mereka mengucapkan perkataan yang benar."

Perintah untuk tidak meninggalkan keturunan dalam keadaan yang lemah telah dijelaskan oleh Allah di dalam ayat di atas. Membangun keturunan yang kuat memerlukan dana yang besar, karena mahalnya investasi di bidang pendidikan. Selain itu harus dipersiapkan modal awal ketika - misalnya — sang anak ingin berwirausaha. Dalam rangka memperkuat keturunan adalah diharuskan untuk berinvestasi yang dananya bisa dimanfaatkan untuk masa depan.

Selanjutnya, perintah untuk ber-investasi selain bermanfaat untuk ketahanan keluarga secara jangka panjang, juga mempunyai kelebihan penyediaan dana untuk pembangunan negara. Sebaik-baik investasi adalah masuk ke dalam sektor riil, terutama jika digunakan untuk berbisnis dan berwirausaha. Akan tetapi jika tidak mampu berwirausaha dikarenakan intensitas kesibukan yang sangat tinggi, menitipkan dana di perbankan syariah, sukük, saham sharîah dan investasi lainnya merupakan alternative lain yang bisa dipilih.

Keempat, alokasi dana yang keempat ketika seseorang mendapatkan income adalah mempersiapkan diri untuk investasi akhirat (final spending). Melalui zakat, infak, sedekah dan wakaf. Seseorang bisa mengeluarkan zakat sesuai dengan perhitungan di setiap bidang usaha yang wajib zakat. Infak dan sedekah bisa dilakukan di mana saja, kapan saja dan tidak terikat jumlah nominalnya. Wakaf bisa dilakukan untuk ikut mensukseskan pembangunan fasilitas publik, dan bukan hanya terkonsentrasi pada pembangunan masjid, musala, sekolah dan kuburan saja. Misalnya ketika di sekeliling melihat jalanan yang rusak, atau jembatan yang ambruk, membiayai perbaikan jalan dan jembatan tersebut merupakan aktivitas wakaf yang pahalanya akan selalu mengalir untuk pewakaf-nya;

1. Alokasi untuk keempat pos di atas haruslah direncanakan dengan baik. Jika ada perencanaan keuangan yang baik dalam sebuah keluarga, maka akan menekan perilaku pembelian yang tidak terencana (impulse buying), terutama untuk produk dan jasa tahsinizyat;

2. Jika keempat pos sudah mendapatkan alokasi dana dan masih ada dana yang tersisa maka pemenuhan kebutuhan tahsiniȳät adalah mubāh. Seseorang diperbolehkan memenuhi keinginan-keinginan (wants) mereka, selama berada dalam batasan tidak boleh isräf (melampaui batas) dan tabdhir (mubazir). 
Islamic models of saving and investment menawarkan solusi atas merebaknya perilaku pembelian yang tidak terencana pada produk dan jasa tahsiniyät. Islamic models of saving and investment ini juga bisa digunakan sebagai acuan untuk manajemen pengelolaan kekayaan rumah tangga yang sesuai dengan ajaran Islam (Islamic family wealth management). Ketika perekonomian sebuah keluarga bisa berdiri kokoh dan kuat, maka secara tidak langsung akan memperkuat perekonomian masyarakat dan selanjutnya bisa memperkuat negara.

Perilaku saving dan investasi yang merupakan inti dari ajaran Islam dalam ekonomi, tidak banyak diimplementasikan dalam subperekonomian terkecil di masyarakat, yaitu keluarga. Padahal perilaku tersebut merupakan kunci untuk membangun perekonomian sebuah negara. Di China misalnya, pada tahun 2001 rata-rata rumah tangga menyisihkan 25,3 persen uang belanja mereka untuk ditabung, sedangkan di Amerika Serikat hanya 6,4 persen pada tahun 2002. Tabungan rumah tangga yang tinggi di China tersebut, memainkan peran kunci dalam pendanaan kebangkitan industri di negerinya. Budaya menabung di China turut menyumbang pertumbuhan pesat perekonomian, karena tingkat investasi yang tinggi. Tingkat investasi tersebut, sama tingginya dengan tingkat tabungan dalam negeri, yang menyediakan dana bagi tinggal landas China sehingga akhirnya industri di China bisa mengalami kemajuan. ${ }^{28}$ Nabi Muhammad pun walau seorang miliarder, karena mendapatkan banyak pendapatan dari ghanimah, dan sumber dana lainnya, akan tetapi beliau hidup dalam keadaan yang sederhana. Prioritas beliau adalah kebutuhan primer bisa terpenuhi dengan baik, dan juga mencukupi kebutuhan primer umatnya yang miskin dengan cara bergiat dalam mengeluarkan zakat, infak, sedekah dan wakaf.

\section{Penutup}

Manusia mempunyai keinginan tidak terbatas yang menurut alGhazālī disebut dengan rughbah dan shabwah, akan tetapi manusia dibekali dengan akal dan budi untuk bisa menentukan arah tujuan hidupnya sesuai dengan rasio. Keinginan-keinginan yang tidak didasari oleh pertimbangan yang mendalam bisa mengakibatkan perilaku impulse buying, ataupun pembelian tidak terencana. Apabila akumulasi dari perilaku tersebut sangat tinggi, dan impulse buying terpusat pada

28 Martin Jacques, When China Rules The World, terj. Noor Cholis dan Jarot Sumarwoto (Jakarta: Kompas, 2011), 177. 
barang atau jasa tahsiniȳät, maka hal ini berpotensi isräf dan tabžr, terlebih jika belum terpenuhi kebutuhan darürȳät, belum melakukan saving dan investasi dan belum mengalokasikan dana untuk zakat, infak, sedekah dan wakaf. Perilaku impulse buying pada produk tahsiniyät juga berakibat pada naiknya supply untuk barang/jasa yang diminta. Jika produk dan jasa tersebut merupakan produk UMKM dan pebisnis dalam negeri maka hal tersebut menjadi positif, karena bisa meningkatkan pendapatan perajin dalam negeri. Akan tetapi jika barang/jasa yang diminati adalah produk dari luar negeri, maka bisa disimpulkan berapa banyak uang penduduk Indonesia yang masuk ke kran asing.

Penelitian ini juga menghasilkan satu model saving dan investasi yang Islami. Penyematan kata islami bukanlah sesuatu yang berlebihan, karena penulis menggali model saving dan investasi tersebut dari al-Qur'ān dan juga dari bahasan tentang konsep maqāsid al-sharíah. Model saving dan investasi yang islami inilah kemudian bisa dijadikan pola untuk manajemen kekayaan keluarga yang sesuai dengan ajaran Islam (Islamic family wealth management).

Keterbatasan dalam penelitian ini adalah bahasan tentang Islamic models of saving and investment yang juga Islamic family wealth management, dipaparkan dengan sangat singkat. Dibutuhkan studi lebih lanjut untuk mengembangkan konsep ini, perspektif Islamic economics. Walaupun begitu, penulis berharap ide singkat ini bisa diimplementasikan dalam perekonomian keluarga, sehingga perilaku impulse buying untuk produk dan jasa yang mengarah ke tabdhir bisa diminimalisir. Harapan penulis ketahanan perekonomian keluarga bisa kokoh, sehingga masa depan keluarga lebih bisa tertata dengan baik.

\section{Daftar Rujukan}

"OJK: Orang Indonesia Makin Konsumtif", dalam https:// ekonomi.kompas.com/read/2015/08/08/110746226/Diunduh 14 Maret 2018, pukul 19.00.

"Penduduk Indonesia Paling Doyan Belanja di Dunia", dalam http://bisnis.liputan6.com/read/813277/ (diunduh 14 Maret 2018, pukul 19.15)

Auda, Jasser. Maqasid al-Shariah as Pbilosophy of Islamic Law a System Approach. Herndon: The International Institut of Islamic Thought, 2008. 
Bakar, Al-Yasa Abu. Metode Istislabi Pemanfaatan Ilmu Pengetahuan dalam Ushul Fiqih. Banda Aceh: CV. Diandra Primamitra Media, 2012.

Dīn (al), Bin Zaghbah 'Izz. al-Maqāsid al-Ämmah li al-Sharīah alIslämīyah. Kairo: Dār al-Ṣafwah li al-Ṭibā'ah wa al-Nashr wa alTawzī', 1996.

Dittmar, H. dan Drury, J. "Self Image-Is It the Bag? A Qualitative Comparison Between Ordinary and Excessive Consumers", Journal of Economic Psychology, Vol. 21, No. 2, 2000.

Fauzia, Ika Yunia dan Ilfitriah, Aniek Masudah. "Perilaku Impulse Buying pada Produk Woman Fashion di Kalangan Konsumen Bisnis

Online". Surabaya: Penelitian Internal PPPM STIE Perbanas Surabaya, 2017.

Fauzia, Ika Yunia dan Riyadi, Abdul Kadir. Prinsip Dasar Ekonomi Islam Perspektif Maqashid al-Shariah. Jakarta: Prenada Media Kencana, Cet. Ke-3, 2017.

Fauzia, Ika Yunia. "Akad Wakalah dan Samsarah sebagai Solusi atas Klaim Keharaman Dropship dalam Jual Beli Online", Islamica: Jurnal Studi Keislaman, Vol. 9, No. 2, 2015.

-----. "Hambatan dalam Pemanfaatan Layanan Internet Banking dan Mobile Banking di Perbankan Syariah Bagi Pelaku Bisnis Online". Surabaya: Penelitian Internal PPPM STIE Perbanas Surabaya, 2017.

-----. "Pemanfaatan E-Commerce dan M-Commerce dalam Bisnis di Kalangan Wirausahawan Perempuan di Indonesia", Journal of Business and Banking, Vol. 5, No. 2, 2015.

----. "Studi Etnografi Makna Shariah Compliance bagi Pebisnis dan Wirausahawan Muslim di Indonesia". Surabaya: Penelitian Internal PPPM STIE Perbanas Surabaya, 2018.

----- "Transcendental Trust dalam Bisnis Online di Kalangan Pengusaha Garment di Indoensia". Surabaya: Penelitian Internal PPPM STIE Perbanas Surabaya, 2016.

----. "Urgensi Implementasi Green Economy Perspektif Pendekatan Dharuriyah dalam Maqashid al-Shariab", Jurnal Ekonomi dan Bisnis Islam, Vol. 2, No. 1, 2016.

----. Etika Bisnis dalam Islam. Jakarta: Prenada Media Kencana, Cet. Ke-3, 2017.

Ghazālī (al), Abū Ḥāmid. Shifä́ al-Ghalīl, Hạdī Ubayd al-Kābish (ed.). Baghdad: Matba'at al-Irshād, 1971. 
Han Y.K., Morgan, Kotsiopulos dan Kang-Park. "Impulse Buying Behavior of Apparel Purchasers", Clothing and Textiles Research Journal, Vol. 9, No. 3, 1991.

Haryudi. "Masyarakat Indonesia Konsumtif, Daya Tarik Pengusaha Asing", dalam https://ekbis.sindonews.com/read/1061097/34 /diunduh tanggal 18 Maret 2018, pukul 21.00.

Jacques, Martin. When China Rules The World, terj. Noor Cholis dan Jarot Sumarwoto. Jakarta: Kompas, 2011.

Japarianto, Edwin dan Sugiharto, Sugiono. "Pengaruh Shopping Life Style dan Fashion Involvement terhadap Impulse Buying Behavior Masyarakat High Income Surabaya", Jurnal Manajemen Pemasaran, Vol. 6, No. 1, 2011.

Krishnan, J. dan Bhuvaneswari, M.V. "A Review of Literature on Impulse Buying Behaviour of Consumers in Brick dan Mortar and Click Only Stores", International Journal of Management Research and Social Science (IJMRSS), Vol. 2, No. 3, 2015.

O'Cass, A. "Fashion Clothing Consumption: Antencedents and Consequences of Fashion Clothing Involvement", European Journal of Marketing, Vol. 38, No. 7, 2004.

Park, E.J., Kim dan Fourney, "A Structural Model of FashionOriented Impulse Impulse Buying Behaviour", Journal of Fashion Marketing and Management, Vol. 10, No. 4, 2006.

Raḥmān (al), Jalāl al-Dīn 'Abd. al-Mașālị̣ al-Mursalah. Mesir: Maṭba'at al-Sa'ādah, 1983.

Raysūnī (al), Aḥmad. Nazarìyat al-Maqạsid ind al-Imām al-Shätibì. Beirut: al-Ma'had al-Ālī li al-Fikr al-Islām, al-Muassasah alJāmi'iyah li al-Dirāsāt wa al-Nashr wa al-Tawzī', t.th.

Rohman, Fatchur. "Peran Nilai Hedonik Konsumsi dan Reaksi Impulsif sebagai mediasi Pengaruh Faktor Situasional terhadap Keputusan Pembelian Impulsif di Butik Kota Malang”, Jurnal Aplikasi Manajemen, Vol 7, No. 2, 2009.

Sari, Elisa Valenta. "Pengelolaan Keuangan: OJK Pendapatan Meningkat, Masyarakat Cenderung Konsumtif', dalam https://www.cnnindonesia.com /ekonomi/20141220 232435-7819533/ (Diunduh 14 Maret 2018, pukul 19.30)

Semuel, Hatane. "Dampak Respon Emosi terhadap Kecenderungan Perilaku Pembelian Impulsif Konsumen Online dengan Sumberdaya yang Dikeluarkan dan Orientasi Belanja Sebagai 
Variabel Mediasi, Jurnal Manajemen dan Kewirausahaan, Vol. 2, No. 2, 2006.

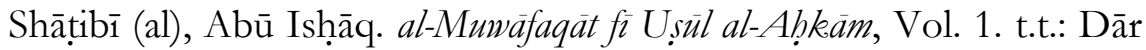
al-Fikr, t.th.

Vazifehdoost, H., A. Rahnama, S. J. Mousavian. "Evaluation of The Influence of Fashion Involvement, Personality Characteristics, Tendency to Hedonic Consumption and Store Environtment on Fashion-Oriented Impulse Buying", Mediterranean Journal of Social Sciences (MCSER Publishing Rome-Italy), Vol. 5, No. 16, 2014. 